\title{
Fulfillment Of Activity Daily Living (ADL) In Breast Cancer Patients Undergoing Chemotherapy At Haji Adam Malik Hospital Medan
}

\author{
Intan Trinanda Sinaga \\ Sumatera Utara Faculty Of Nursing \\ E-mail: intansinaga@gmail.com
}

\begin{abstract}
Breast cancer arises as a result of abnormal cells forming in the breast at an uncontrolled and irregular rate. There are several types of treatment for breast cancer patients and one of them is chemotherapy. The frequency of chemotherapy can cause several effects that can worsen the patient's functional status. Functional status is an ability to perform daily tasks that include work, self-care, and maintenance of family or social roles. This study aims to identify ADL compliance in breast cancer patients undergoing chemotherapy. This study used a descriptive design, the sample was taken using a non-probability sampling method, namely accidental sampling and the instrument used was a questionnaire compiled using a Likert scale. The reliability test of this study used a Cronbach Alpha of 0.917. Data collection was carried out from September 2015 to August 2016. The description of ADL fulfillment of breast cancer patients undergoing chemotherapy was described to determine the frequency and percentage. The results showed that the fulfillment of $A D L$ in breast cancer patients undergoing chemotherapy was independent (20 people, 54.1\%), partial dependence (10 people, $27 \%$ ), and total dependence (7 people, $18.9 \%$ ). It can be concluded that most breast cancer patients undergoing chemotherapy can carry out their Activity Daily Living with an independent level of ability. The description of ADL fulfillment of breast cancer patients undergoing chemotherapy is described to determine the frequency and percentage. The results showed that the fulfillment of $A D L$ in breast cancer patients undergoing chemotherapy was independent (20 people, 54.1\%), partial dependence (10 people, $27 \%$ ), and total dependence (7 people, $18.9 \%$ ). It can be concluded that most breast cancer patients undergoing chemotherapy can carry out their Activity Daily Living with an independent level of ability. The description of ADL fulfillment of breast cancer patients undergoing chemotherapy is described to determine the frequency and percentage. The results showed that the fulfillment of ADL in breast cancer patients undergoing chemotherapy was independent (20 people, 54.1\%), partial dependence (10 people, $27 \%$ ), and total dependence (7 people, 18.9\%). It can be concluded that most breast cancer patients undergoing chemotherapy can carry out their Activity Daily Living with an independent level of ability.
\end{abstract}

Keywords: Daily Living (ADL), Breast Cancer, Chemotherapy

\section{Introduction}

Breast cancer is the leading cause of death in women worldwide. The National Cancer Institute revealed that of the 7.6 million deaths in the world that occur due to disease, $13.0 \%$ of these deaths are caused by cancer and 458,000 are cases of breast cancer. The American Cancer Society (ACS) calculates that in 2013, there were 64,640 cases of breast cancer and about 39,620 women die each year from cancer (American Cancer Society, 2013). In most countries in Asia, the incidence of breast cancer based on the Age Standardized Ratio (ASR) is still low even though the figure reaches more than 50 per 100,000 population (world standardized rate) in Manila, Philippines and South Karachi, Pakistan.

Cancer with the highest proportion suffered by women is breast cancer, which is 26 per 100,000 people, then cervical cancer, which is 16 per 100,000 people. This fact states that breast cancer is a disease case that mostly affects women in Indonesia and in other countries (Audrina, 2014). Data from the Hospital Information System (SIRS) in 2011 states that breast cancer ranks first, namely $16.85 \%$ of all inpatient cancer patients in Indonesia. According to Basic Health Research (Riskesdas, 2008), the prevalence of cancer is the sixth of the national disease pattern and is the seventh leading cause of death with a percentage of 5.7\%. In Medan, especially at the Central General Hospital H. Adam Malik from January to October 2015 obtained as many as 401 breast cancer patients who were hospitalized (Medical Records, 2015). The data obtained from the medical records of Dr. General Hospital. Pringadi Medan in 2009-2010 there were 106 
cases of breast cancer hospitalized. Breast cancer is an important public health problem and must be considered because of its high morbidity and mortality.

Every breast cancer patient must know the importance of taking treatment for the breast cancer he suffers. Treatment of breast cancer is very dependent on the type, location and extent of spread. There are several types of treatment for breast cancer patients and one of them is chemotherapy. Chemotherapy is a type of cancer treatment that uses special drugs to kill cancer cells (Yudissanta \& Ratna, 2012). According to the Breast Cancer Organization (2012), the side effects that will appear on chemotherapy depend on the number of drugs obtained, the period of treatment and the general health condition of the patient. The frequency of chemotherapy can cause several effects that can worsen the patient's functional status. The most common side effects of chemotherapy include bone marrow suppression, Gastrointestinal symptoms such as nausea, vomiting, weight loss, taste changes, constipation, diarrhea, alopecia, fatigue, emotional changes, and changes in the nervous system (Nagla, 2010 in Melia, 2013). Functional status is an ability to perform daily tasks that include work, self-care, and maintenance of family or social roles. In addition to the side effects above, Lee (2005) said that in some conditions the symptoms associated with chemotherapy can reduce the daily activities of breast cancer patients and cause them to only be bedridden and unable to meet their needs in activities. Along with increasing pain, fatigue, and loss of appetite experienced by cancer patients, their body functions are getting weaker.

Women who have breast cancer may have feelings of inadequacy because they are unable to manage daily activities such as taking care of the house and unable to take care of themselves and their families. In a study conducted by Fangel (2012) stated that women with breast cancer have negative changes in their ability to carry out daily activities and social participation. And this situation causes the sufferer to be depressed, useless, and can impair their quality of life.

\section{Method}

This study uses a descriptive research design. The design of this study used a cross-sectional design to observe ADL compliance in breast cancer patients undergoing chemotherapy at $\mathrm{H}$. Adam Malik Hospital Medan.

This study uses an internal consistency reliability test because it has the advantage that the instrument is only given once with one form of instrument to one study subject (Demsey \& Dempsey, 2002). This reliability test aims to measure the strength of the instrument so that it can be used for subsequent research in the same scope. A good instrument or measuring instrument is a measuring instrument that gives the same results when used several times on the same subject group (Azwar, 2003). The reliability test was carried out on 10 respondents at the DR Pirngadi Hospital in Medan who were in accordance with the criteria of the research sample and were not included in the research sample. The reliability test was carried out using cronbach alpha.

In conducting the analysis, the data is first processed with the aim of converting the data into information. In the data processing process there are steps that must be taken, including:

Editing is an attempt to re-check the correctness of the data obtained or collected. Editing is done at the data collection stage or after the data is collected. coding is an activity of assigning numerical codes (numbers) to data consisting of several categories. Giving this code is very important when processing and analyzing data using a computer. Usually in coding, a list of codes and their meanings is also made in a code book to make it easier to see the location and meaning of a code from a variable.

Entry data, the activity of entering the data that has been collected into a master table or computer data base, then making a simple frequency distribution or it could be by making a contingency table. Performing analytical techniques, in carrying out this technique, especially on research data, will use applied statistical science that is adapted to the purpose to be analyzed. If the research is descriptive, it will use descriptive statistics. Descriptive statistics (illustrating) are statistics that discuss ways to summarize, present, and describe data with the aim of making it easy to understand and have more meaning (Hidayat, 2009).

\section{Analysis And Results}

The results showed that more patients were in the premenopausal period (30-50 years) as many as 22 (59.5\%), the number of chemotherapy patients underwent was more in 6 , namely 13 (35.1\%), the most common type of chemotherapy. The most widely used adjuvants are $23(62.2 \%)$ and the stage of cancer 
Fulfillment Of Activity Daily Living (ADL) In Breast Cancer Patients Undergoing Chemotherapy At Haji Adam Malik Hospital Medan-Intan Trinanda SInaga

experienced by patients is more at stage 3, namely 17 (45.9\%). The characteristics of the respondents can be seen in table 1.

Table 1 Distribution of Frequency and Percentage Based on Patient Characteristics $(n=37)$

\begin{tabular}{|c|c|c|}
\hline Characteristics & Frequency & Percentage (\%) \\
\hline \multicolumn{3}{|l|}{ Age } \\
\hline $30-50$ & 22 & 59.5 \\
\hline 50 & 15 & 40.5 \\
\hline \multicolumn{3}{|c|}{ Number of Chemotherapy Undergoing 2} \\
\hline 3 & 7 & 18.9 \\
\hline 4 & 6 & 16.2 \\
\hline 5 & 4 & 10.8 \\
\hline 6 & 7 & 18.9 \\
\hline Types of Chemotherapy & 13 & 35.1 \\
\hline \multicolumn{3}{|c|}{ Neoadjuvant Adjuvant } \\
\hline Cancer Stage & 14 & 37.8 \\
\hline 1 & 23 & 62.2 \\
\hline \multicolumn{3}{|l|}{2} \\
\hline 3 & 1 & 2.7 \\
\hline 4 & 12 & 32.4 \\
\hline \multirow[t]{3}{*}{ Total } & 17 & 45.9 \\
\hline & 7 & 18.9 \\
\hline & 37 & 100 \\
\hline
\end{tabular}

Source: Primary Data

\subsection{Activity Daily Living (ADL) in Breast Cancer Patients Undergoing Chemotherapy}

The results of Activity Daily Living (ADL) research on breast cancer patients who underwent chemotherapy at $\mathrm{H}$. Adam Malik Hospital Medan showed that more breast cancer patients underwent activities independently, namely as many as 20 (54.1\%). For more details can be seen in table 5.2.

Table 2. Frequency distribution of Activity Daily Living ( $A D L)$ in breast cancer patients undergoing chemotherapy at $H$. Adam Malik

\begin{tabular}{|c|c|c|}
\hline \multicolumn{3}{|c|}{ Hospital Medan $(n=37)$} \\
\hline Activity Daily Living (ADL) & Frequency & Percentage (\%) \\
\hline Total dependency & 7 & 18.9 \\
\hline Independent partial dependency & 10 & 27.0 \\
\hline & 20 & 54.1 \\
\hline Total & 37 & 100 \\
\hline
\end{tabular}

Source: Primary Data

\subsection{Distribution Frequency Characteristics Demographics with Level Patient's Ability in Undertaking Daily Living (ADL) Activities}

From the results of the study, it can be seen that the level of independent ability is more at the age of 46 55 years, and total dependence is also at the age of 46-55 years. Adjuvant chemotherapy is a type of chemotherapy in which the patient's ability level is more independent. For more details, see table 3.

Table. 3 Frequency distribution of Age Characteristics by Ability Level Patients Undergoing Activity Daily Living (ADL)

\begin{tabular}{cccc}
\hline $\begin{array}{c}\text { Characteristics } \\
\text { Demographics }\end{array}$ & $\begin{array}{c}\text { Dependency } \\
\text { Total } f()\end{array}$ & $\begin{array}{c}\text { Dependency } \\
\text { Partial } f()\end{array}$ & Independent $f()$ \\
\hline Age & & & \\
30-50 years & $4(18.2)$ & $5(22.7)$ & $13(59.1)$ \\
50 years & $3(20)$ & $5(33.3)$ & $7(46.7)$ \\
\hline
\end{tabular}

Source: Primary Data

Table. 4 Frequency Distribution of Characteristics of Chemotherapy Types with the Patient's Ability Level in Undertaking Daily Living

\begin{tabular}{cccc}
\multicolumn{4}{c}{ Activities (ADL) } \\
\hline Characteristics & $\begin{array}{c}\text { Dependency } \\
\text { Demographics }\end{array}$ & $\begin{array}{c}\text { Dependency } \\
\text { Partial } f()\end{array}$ & Independent $f()$ \\
\hline Types of Adjuvant & & & \\
Neoadjuvant & $3(21.4)$ & $4(28.6)$ & $7(50)$ \\
Chemotherapy & $4(17.4)$ & $6(26.1)$ & $13(56.5)$ \\
\hline
\end{tabular}

Source: Primary Data 
Based on the results of the study showed that most of the age of respondents who suffered from breast cancer were respondents in the premenopausal period, namely in the age range of 30-50 years. The incidence of breast cancer will increase rapidly at reproductive age, then after that it increases at a lower rate ( $\mathrm{R}$ Indrati, 2010). The results showed that the oldest respondent was 72 years old, and the youngest was 32 years old. Several research results report that the risk of cancer increases with age, the possibility of breast cancer developing at the age of over 40 years (Sihombing, 2014). As we age, there is an accumulation of overall risk factors, cell repair mechanisms tend to become less effective with aging, and the immune system declines. Survival rates will also affect the number of cancer patients by age. Based on the research of Sihombing and Sirait (2014), the survival rate is influenced by the stage and treatment of cancer. The stage of cancer will certainly develop along with the increasing time or age of the patient, thereby reducing the patient's survival rate (Pradana, 2013). This may be one of the factors for the low number of breast cancer patients in old age (65 years) found in this study. Increasing age is one of the risk factors for breast cancer, allegedly due to the influence of hormonal exposure, especially for a long time, especially the hormone estrogen and carcinogenic substances, and there is also the influence of other risk factors that take time to induce cancer. Based on the research of Sihombing and Sirait (2014), the survival rate is influenced by the stage and treatment of cancer. The stage of cancer will certainly develop along with the increasing time or age of the patient, thereby reducing the patient's survival rate (Pradana, 2013). This may be one of the factors for the low number of breast cancer patients in old age (65 years) found in this study. Increasing age is one of the risk factors for breast cancer, presumably due to the influence of hormonal exposure, especially the hormone estrogen and carcinogenic substances, and there is also the influence of other risk factors that take time to induce cancer. Based on the research of Sihombing and Sirait (2014), the survival rate is influenced by the stage and treatment of cancer. The stage of cancer will certainly develop along with the increasing time or age of the patient, thereby reducing the patient's survival rate (Pradana, 2013). This may be one of the factors for the low number of breast cancer patients in old age (65 years) found in this study. Increasing age is one of the risk factors for breast cancer, presumably due to the influence of hormonal exposure, especially the hormone estrogen and carcinogenic substances, and there is also the influence of other risk factors that take time to induce cancer. The stage of cancer will certainly develop along with the increasing time or age of the patient, thereby reducing the patient's survival rate (Pradana, 2013). This may be one of the factors at least breast cancer patients in old age (65 years) found in this study. Increasing age is one of the risk factors for breast cancer, presumably due to the influence of hormonal exposure, especially the hormone estrogen and carcinogenic substances, and there is also the influence of other risk factors that take time to induce cancer. The stage of cancer will certainly develop along with the increasing time or age of the patient, thereby reducing the patient's survival rate (Pradana, 2013). This may be one of the factors for the low number of breast cancer patients in old age (65 years) found in this study. Increasing age is one of the risk factors for breast cancer, presumably due to the influence of hormonal exposure, especially the hormone estrogen and carcinogenic substances, and there is also the influence of other risk factors that take time to induce cancer.

From the results of this study, it showed that breast cancer patients who underwent chemotherapy at H. Adam Malik Hospital mostly had the ability to be independent in undergoing their ADL as many as 20 (54.1\%). But the level of patient dependence for the total and partial is not too much different. The level of partial dependence is $10(27 \%)$, and total dependence is $7(18.9 \%)$. This shows that the level of total dependence requires attention because the existing data shows quite a lot of cases. The daily activities that many patients do in the independent category are preparing food for their family and themselves, shopping for household needs, using the telephone, reading, and writing. For the ability level of partial dependence such as using public transportation, treatment. At the level of ability, total dependence is more on activities such as washing, participating in religious activities and the community's environment. Researchers see that the level of ability possessed by patients is supported by the spirit and family support that is always there for them. So, although there are effects from the treatment they receive from the chemotherapy they are undergoing, not all of them make them feel helpless. Physical activity in cancer patients has been shown to improve physical function and performance, reduce levels of fatigue (fatigue), and even improve quality of life (Hatchett \& Bellar, 2012). Physical activity can also improve, even improve cognitive abilities, because it increases blood flow to the brain (Gligroska and Manchevska, 2012). When the body is functioning optimally physically, Then psychology follows. If the individual has a positive physical condition, the mood will be positive. This will be able to support the level of independence in carrying out their ADL.

\section{Conclusion}


Fulfillment Of Activity Daily Living (ADL) In Breast Cancer Patients Undergoing Chemotherapy At Haji Adam Malik Hospital Medan-Intan Trinanda SInaga

Based on the results of this study, it can be concluded that from 37 respondents the description of the fulfillment of Activity Daily Living (ADL) in breast cancer patients undergoing chemotherapy at $\mathrm{H}$. Adam Malik Hospital Medan is in the independent category. From the demographic data, it can be seen that the characteristics of the respondents: age 46-55 years, the amount of chemotherapy 6 times, the type of adjuvant chemotherapy, stage 3 cancer stage. partial dependence (10 people, $27 \%$ ), and total dependence (7 people, $18.9 \%$ ). This shows that the level of ability of breast cancer patients who undergo chemotherapy can mostly carry out their activities in the independent category.

\section{References}

Agung, I. 2006. Test of Reliability and Validity of the Index of Activity Daily Living Barthel to measure Basic Functional Status in the Elderly in RSCM. Taken January 03, 2016 fromhttp://www.digilib.ui.ac.id

American Cancer Society. 2013. Breast Cancer. Retrivied on October 22, 2013.

Audrina, Gressa W. 2014. Factors Affecting the Success Rate of Giving Chemotherapy to Breast Cancer Patients at Dr.Soetomo Hospital Using Ordinal Logistic Regression. Surabaya: Sepuluh Nopember Institute of Technology (ITS).

Aziz, M, et al. 2006. National Reference Book for Gynecological Oncology. Jakarta: Bina Pustaka Sarwono Prowirohardjo.

Choirul, I. 2012. A lot of rest is not good advice for cancer patients. Taken date 12 October 2015 from http://www.cross.me/go/sido.mi.com/many-rest-not-advice-good- for-cancer.

Cour, K. 2009. Activity and Meaning Making in the Everyday Lives of People with Advanced Cancer. Cambridge: Cambridge University Press.

Dempsey, Patricia Ann \& Dempsey, Arthur d. (2002). Nursing Research: textbooks and exercises/ Patricia Ann Dempsey \& Arthur D. Dempsey; transliteration, Palupi W.; editor, Dian A. ed. 4. Jakarta : EGC.

Fangel, Leticia M. 2012. Quality of Life and Daily Activities Performance After Breast Cancer Treatment.

Gligroska and Manchevska. 2012. The effect of Phsycal Activity on Cognition-Physiological Mechanism. http://www.ncbi.nlm.nih.gov/pmc/articles/PMC.

Grace, Pierce A. 2007. At a Glance Surgery. Jakarta: Publisher Erlangga Hatchett, AG and Bellar, DM Physiologic and behavioral outcomes of a physical activity intervention designed specifically for survivors of cancer: a pilot study (2012) Integrative Medicine: A Clinician's Journal.

Jong, Wim De. 2005. Cancer, what is it?. Jakarta:Arcan.

Melia. (2013). The Relationship between Frequency of Chemotherapy and Functional Status of Cancer Patients Undergoing Chemotherapy at Sanglah Hospital Denpasar. Taken date September 2015 fro http://ojs.unud.ac.id/index.php/coping/article/download/6123/4614.

Notoadmodjo, S. (2005). Health Research Methodology. Jakarta: PT Rineka Cipta.

Nursal, Dien. 2009. Measurement of Physical Activity in the Elderly, vol. 3. Journal of Public Health, 39-42.

Nursalam. (2009). Concept and Application of Nursing Research Methodology Edition 2: Guidelines for Thesis, Thesis, and Nursing Research Instruments. Jakarta: Salemba Medika.

Panggabean, KN (2014). Overview of Activities of Daily Life and Hearing Loss in the Elderly at UPT Social Services for Elderly and Toddlers in Binjai and Medan Regions. Medan : USU.

Pudjiastuti, Sri Sunni. 2003. Physiotherapy in the Elderly. Jakarta: EGC Medical Book Publisher.

Saint. D. 2007. Activities Of Daily Living in Women with Advanced Breast Cancer. Oncology Nursing Forum: Proquest. 
Sinaga. L. 2013. Characteristics of Breast Cancer Patients who are Inpatient at St. Elisabeth Medan. University of Northern Sumatra.

Sjamsuhidayat, R. 2005. Textbook of Surgery. Jakarta: EGC Medical Book Publisher.

Sihombing, M. 2014. Risk Factors for Breast Tumors in Women Age 25- 65 years old in Five Villages, Central Bogor District. ejournal.litbang.depkes.go.id/index.php/kespro/article/view/3895. Retrieved August 16, 2016.

Sihombing, M. and Sirait, NM 2007. Survival Rates for Ovarian Cancer Patients at Dr. Hospital. Cipto Mangunkusumo Jakarta, (online),(http://mki.idionline.org/index.php?uPage=mki.mki_dl\&smod=mki\&sp=pu blic\&key=MTc1LTIz, accessed 16 August 2016).

Siregar, Syofian. 2013. Parametric Statistics for Quantitative Research. Jakarta: PT Bumi Aksara.

Solehah, M H. 2014. Behavioral Activation To Reduce Depression Levels in Patient Cancer Breast http://etd.repository.ugm.ac.id/index.php?mod=penelitian_detail\&sub=PenelitianDetail\&act=view\&typ=html\&bo ok id=68343. Accessedon 15 August 2016.

Palu, M. 2014. Lost Potential Based on Health Related of Life in Breast Cancer Patients in Makassar, South Sulawesi. Makassar: Fac. Hasanuddin University Medicine.

Pradana. 2013. Relationship of Quality of Life with Palliative Care Needs in Cancer Patients at Sanhlah Hospital Denpasar. Denpasar: Udayana University.

Bali Pink Ribbon Foundation. 2012. The Breast Book of Myths, Truths, and Facts. Taken November 20, 2015 fromhttp://www.balipinkribbon.com.

World Health Organization. 2010. Cancer. Retrivied on October 19, 2015 fromwww.who.int/cancer/en/.

Solehah, M H. 2014. Behavioral Activation To Reduce Depression Levels in Patient Cancer Breast. http://etd.repository.ugm.ac.id/index.php?mod=penelitian_detail\&sub=PenelitianDetail\&act=view\&typ=html\&bo ok_id=68343. Accessedon 15 August 2016 